\title{
Basic Requirements of Teaching
}

\author{
J. Jayapriya \\ Asst. Professor, School of Education, \\ SCSVMV University, Enathur
}

\begin{abstract}
Teaching is uncertain and interactional. Part of teaching well is using a combination of one's own talents, insights, skills, and professional judgments to encourage students' learning and development. It is a very humanistic profession, and compassion is the utmost feeling of understanding, and showing others you are concerned about them. A compassionate teacher models that characteristic to the students with her/his actions, and as a result students will be more open to understanding the world around them. Teaching is difficult partly because classrooms are complex. First, teachers are required to serve in several roles. They need to serve as advocate, instructor, observer, evaluator, coach, activities director, supply master, tech support, and confidante, for instance. In their varied roles, teachers make many decisions about different kinds of issues. Teachers make hundreds of decisions per day. They need to think about students' safety, their learning, and their other needs simultaneously, all while they also consider their own personal and professional issues.
\end{abstract}

Keywords: Teacher, Student, Classroom, Requirement, Teaching

\section{Introduction}

Teaching is an interactive process, primarily involving class room talk which takes place between teacher and pupil and occurs during certain definable activity. Teaching is complex because it reaches into time both before and after face to-face interaction with students. It requires preparation, and it requires reflection and revision. As a result, many teachers feel like their work is never finished. Because classrooms are complex, it takes years to master the craft of teaching. Teaching becomes complicated by the fact that teachers usually pursue many and sometimes conflicting goals.

\section{Meaning of Teaching}

Teaching is an arrangement and manipulation of a situation in which an individual will seek to overcome and from which he will learn in the course of doing so."

\section{Definition of Teaching}

Teaching includes all the activities of providing education to other. The person who provides education is called teacher. The teacher uses different method for giving best knowledge to his student's .He tries his best to make understand students. His duty is to encourage students to learn the subjects.

\section{Objectives of Teaching}

- To bring desired changes in pupils.

- To shape behaviour and conduct.

- Acquisition of knowledge

- To improve the learning skills of students.

- Formation of belief.

- To provide a social and efficient member to the society.

\section{Basic Requirements of Teaching}

- The teacher

- The Learner

- The Subject

- The Environment

The Teacher

The teacher is an innovator of information and knowledge. He is the creator and transmitter of knowledge, values and ethos to our youngsters for latter's physical, mental, emotional and social development. In the process of teaching-learning, the teacher is the main vehicle, and he knows what is right and what is wrong in the society. The teacher masters over his subject and uses an effective language for the communication in order to bring a 
positive change in the behavior of the learner. Since, it is the age of science and technology, the teacher ought to have a sound knowledge of science and technology. He should therefore use the latest means of media communication in the process of teaching. Teachers always look to make things better and improve things in and outside of the classroom. Building a community is something a great teacher seeks to do in the classroom and extends that to the entire school and its community.

\section{The Learner}

The learner is a dependent one and immature. He has to cooperate in the teaching-learning process with the teacher and try to get as much information and knowledge as possible from him. He must follow the teacher for understanding and getting knowledge. The learners may be categorized as the students of primary schools, elementary schools, secondary schools, senior secondary schools, colleges or universities.

\section{The Subject}

The subject is the main concern in the whole endeavor of teaching and learning process. The topic is generally decided by the teacher but the learner can also contribute in deciding a topic, so that, a balanced and harmonious development takes place. It is for the teacher to prepare necessary charts, maps, tables and models that pertain to the decided topic. Media based technological and scientific aids may also be made available by the teacher to make the teaching more interesting and understandable.

\section{The Environment}

A teacher is anyone who affects the environment so that others learn. The learner's growth and all round development are the main objectives of teaching. This is possible only when there is a suitable environment for the teaching-learning process. The teacher as such creates such environment and nurtures the' learner in that environment. Learners are not passive objects. For long, the child or the learner was viewed as a natural or given category. This undermined the importance of the fact that the development of the learner is intimately linked to changes in the socio cultural and historical conditions in a given society.

\section{Conclusion}

Teaching is more than telling too, because it involves listening. When people learn, they try to figure things out, to make sense of new information. One effective way to help learners understand things is to listen to their musings and questions. Listening is an important strategy that teachers can employ to slow down the presentation of new information, to give learners an opportunity to sort things out, and to help learners discover what they think. Finally, because teaching is interactional, listening is an informal assessment strategy; it gives us information about the learners' reasoning that can be used to guide our instructional decisions. a great teacher shows kindness to students, colleagues, parents and those around her/him. It truly changes the environment in the classroom and school. Everyone looks at a great teacher and they want to be a better teacher, they want to be a better student, even better, they want to be a better person. A great teacher uncovers hidden treasures, possibilities and magic right before everyone's eyes.

\section{References}

Retrieved June 5, 2017 from http:/quicknet.in/topic/teaching-characteristics-andbasic-requirements/

Retrieved June 5, 2017 from http://www.indiastudychannel.com/forum/792What68 --definition-Teaching.aspx

Retrieved June 5, 2017 from https://www.edutopia.org/discussion/heart-teachingwhat-it-means-be-great-teacher

Retrieved June 5, 2017 from https://www.pea rsonhighered.com/assets/samplechapter/0/1/3/2/01325 65498.pdf

Schank, C.R. \& Jona, M.Y. (1991). "Empowering the student: New perspectives on the design of teaching systems", The Journal of the Learning Sciences, vol. 1, no 1, pp. 7-35.

Pratt, D. D. (1992). Conceptions of teaching, Adult Education Quarterly, 42, 203-220. 